\title{
PENGARUH PENERAPAN MODEL TALKING STICK DENGAN BANTUAN MEDIA CHOOSE NUMBER TERHADAP HASIL BELAJAR BIOLOGI DI SMP NEGERI 3 SUNGGUMINASA KABUPATEN GOWA
}

\author{
Ikra Safitri \\ Fakultas Tarbiyah dan Keguruan, UIN Alauddin Makassar \\ Kampus II Jalan H. M Yasin Limpo Nomor 36 Samata-Gowa \\ Sulawesi Selatan 92118, Telepon (Hp) : 082346518143 \\ E-mail : ikrasafitry@gmail.com \\ Misykat Malik Ibrahim \\ Fakultas Tarbiyah dan Keguruan, UIN Alauddin Makassar \\ Kampus II Jalan H. M Yasin Limpo Nomor 36 Samata-Gowa \\ Sulawesi Selatan 92118, Telepon (Hp) 081353320999 \\ E-mail : mikka_97@yahoo.com

\begin{abstract}
Nursalam
Fakultas Tarbiyah dan Keguruan, UIN Alauddin Makassar

Kampus II Jalan H. M Yasin Limpo Nomor 36 Samata-Gowa

Sulawesi Selatan 92118, Telepon (Hp) : 081342007864

E-mail : nursalam_ftk@uin-alauddin.ac.id
\end{abstract}

\begin{abstract}
Abstrak
Tujuan dalam penelitian adalah untuk: 1) Mengetahui hasil belajar biologi peserta didik di SMP Negeri 3 Sungguminasa Sungguminasa yang diajar tanpa menerapkan model talking stick dengan bantuan media choose number 3) Menganalisis perbedaan hasil belajar biologi antara peserta didik yang yang diajar dengan menerapkan model talking stick dengan bantuan media choose number 2) Mengetahui hasil belajar biologi peserta didik di SMP Negeri 3 diajar dengan model talking stick dengan bantuan media choose number dan peserta didik yang diajar tanpa model talking stick dengan bantuan media choose number. Dalam penelitian ini merupakan suatu penelitian Quasi Experimental dengan menggunakan desain penelitian Pretest-Postest Control Group Design. Sampel pada penelitian ini adalah kelas VIII A dengan jumlah 35 peserta didik dan kelas VIII $\mathrm{H}$ yang berjumlah 35 peserta duduk. Dengan menggunakan teknik pengambilan sampel yang digunakan adalah teknik simple random sampling . Instrumen yang digunakan untuk mengetahui hasil belajar peserta didik berupa tes pilihan ganda sebanyak 20 nomor. Teknik analisis data pada penelitian ini adalah analisis statistic deskriftif dan analisis statistic inferensial dengan menggunakan
\end{abstract}


uji-t. Berdasarkan dari hasil analisis statistik deskriptif, dan diperoleh nilai ratarata dari kedua kelompok tersebut, dengan menggunakan kelas eksperimen yang diajar dengan menggunakan model talking stick dengan bantuan media choose number sebesar 75,58. Pada kelas kontrol yang diajar dengan tanpa menggunakan model talking stick dengan bantuan media choose number sebesar 67,41. Sedangkan berdasarkan hasil analisis inferensial menggunakan uji-t diperoleh nilai sign sebesar 0,000 yang lebih kecil dari pada $\alpha$ sebesar 0,05 $(\operatorname{sign}<\alpha)$ dengan demikian dapat disimpulkan bahwa $\mathrm{H}_{0}$ ditolak. Jadi terdapat perbedaan yang signifikan antara model talking stick dengan bantuan media choose number dengan tanpa yang diajar menggunakan model talking stick dengan bantuan media choose number terhadap hasil belajar biologi peserta didik dikelas VIII SMP Negeri 3 Sungguminasa Kabupaten Gowa.

Kata kunci: Model Talking Stick, Choose Number dan Hasil Belajar

\begin{abstract}
The purpose of the research was to: 1) Knowing the results learning of biology learners in SMP Negeri 3 Sungguminasa that in teach by applying the talking stick model with the help of choose number. 2) Knowing the results of biology learners in SMP Negeri 3 Sungguminasa are in the teaching without applying the model talking stick with the help of the media choose number. 3) Analyzing the difference of biology learning outcomes between learners who are taught by talking stick model with the help of media choose number and learners who are taught without a talking stick model with the help of the media choose number. This research is a research Quasi Experimental by research design pretestposttest control group design. The sample of this study is the class VIII A which amounts to 35 students and class VIII H which amounts to 35 students. Technique taking sample that in use is technique simple random sampling. Instrument that in use for knowing results learners learn form test multiple choice as much 20 number. Analysis techniques data that in use is analysis statistics descriptive and analysis statistics inferential with test-t. Based on results analysis statistics descriptive, in earn average from second group the, that is class experiment that in teaching with use model talking stick with help media choose number amount 75,58. On class control that in teaching with without use model talking stick with help media choose number amount 67,41. While based on results analysis inferential use test-t in earn value sign amount 0,000 that more small from on $\alpha$ amount $0,05($ sign $<\alpha)$ with thereby could in conclude that $H_{0}$ in reject. So there difference that significant between model talking stick with help media choose number with without that in teach use model talking stick with help media choose number to results learn biology learners in class VIII SMP Negeri 3 Sungguminasa Kabupaten Gowa.
\end{abstract}

Keywords: Model Talking Stick, Choose Number and results learn 


\section{PENDAHULUAN}

Pendidikan merupakan suatu unsur terpenting dalam mewujudkan kemajuan suatu bangsa, karena maju mundurnya suatu bangsa pada masa kini atau masa mendatang sangat ditentukan oleh pendidikan. Pendidikan yang bermutu merupakan hal yang sangat penting dalam kemajuan suatu bangsa. Meningkatkan mutu pendidikan merupakan cara untuk menjadikan pendidikan di Indonesia menjadi lebih baik dan berkualitas. Jadi dengan pendidikan yang berkualitas juga akan membentuk manusia berkualitas kedepannya (Oemar Hamalik, 2001: 79).

Banyak cara yang digunakan untuk meningkatkan mutu proses pembelajaran. Namun demikian banyak juga dijumpai bukti yang menunjukkan proses pembelajaran di sekolah kurang memuaskan (Budimansyah dan Dasim, 2002: 138). Agar proses pembelajaran menjadi efektif dan menyenangkan, perlu adanya inovasi berbagai strategi pendekatan sehingga tujuan utama untuk meningkatkan mutu pendidikan dapat tercapai.

Pembelajaran IPA yang berlangsung pada Sekolah Menengah Pertama (SMP) saat ini masih banyak yang menggunakan sistem penyampaian klasikal, yaitu sistem yang bertumpu pada aktivitas guru atau guru lebih aktif dalam kelas dibandingkan dengan peserta didik. Pada umumnya guru cenderung menggunakan metode ceramah dalam mengajar karena mudah dilakukan dan cepat. Bertumpunya proses belajar mengajar pada guru menimbulkan kurang tumbuh berkembangnya sikap kemandirian belajar pada anak. Hal ini berakibat pada anak akan yang cenderung tergantung pada guru dan sekolah dalam belajar. Tanpa guru dan sekolah peserta didik merasa tidak dapat belajar dan tidak perlu belajar secara teratur. Sikap ini bahkan dapat tumbuh dalam diri orang tuanya, sehingga sekolah dan guru dianggap sebagai satu-satunya pihak yang bertanggung jawab atas keberhasilan anak dalam belajar.

Hasil wawancara yang lakukan dengan salah seorang guru kelas VIII IPA pada tanggal 10 Januari 2017 di SMP Negeri 3 Sungguminasa diperoleh informasi bahwa model yang selama ini di gunakan guru di sekolah itu kerap kali dianggap sangat membosankan bagi peserta didik. Mengajar tak ubahnya proses mendongeng yakni guru menjelaskan didepan kelas, memberikan contoh soal, dan menugaskan peserta didik untuk mengerjakan soal-soal. Sehingga tujuan yang ingin dicapai dalam pembelajaran tidak terpenuhi dan keaktifan peserta didik di dalam kelas kurang tersalurkan. Oleh karena itu, perlu dilakukan suatu inovasi dalam proses pembelajaran dengan menerapkan suatu model pembelajaran yang mampu mengaktifkan peserta didik dan mampu membantu guru untuk merangsang segala bentuk kemampuan peserta didik dan keterampilannya.

Model pembelajaran adalah suatu rencana atau pola yang dapat digunakan untuk membentuk kurikulum, merancang bahan-bahan pembelajaran, dan membimbing pembelajaran dikelas atau yang lain. Model pembelajaran merupakan kerangka konseptual berupa pola prosedur sistematik yang dikembangkan berdasarkan teori dan digunakan dalam menorganisasikan proses belajar mengajar untuk mencapai tujuan belajar (Rusman, 2010:152). 
Berbagai jenis model pembelajaran telah diperkenalkan oleh para akli yang banyak diterapkan dalam pembelajaran dengan menyesuaiakan karakteristik materi pelajaran dan karakteristik peserta didik. Jenis-jenis model pembelajaran yang dimaksudkan diantaranya (1) model pembelajaran kontekstual merupakan konsep belajar yang mendorong guru untuk menghubungkan antara materi yang diajarkan dengan situasi dunia nyata peserta didik. Pembelajaran ini mendorong peserta didik membuat hubungan antara pengetahuan yang dimilikinya dan penerapannya dalam kehidupan mereka sehari-hari. Pengetahuan dan keterampilan peserta didik diperoleh dari usaha peserta didik mengkonstruksi sendiri pengetahuan dan keterampilan baru ketika peserta didik belajar; (2) Model Pembelajaran Problem Based Learning (PBL) merupakan sebuah model pembelajaran yang menyajikan masalah kontekstual sehingga membuat peserta didik untuk belajar. Fokusnya tidak banyak pada apa yang sedang dikerjakan peserta didik tetapi pada apa yang peserta didik pikirkan selama mereka mengerjakannya. Guru memfungsikan diri sebagai pembimbing dan fasilitator sehingga peserta didik dapat belajar untuk berfikir dan menyelesaikan masalahnya sendiri; (3) Model pembelajaran Talking Stick adalah salah satu model pembelajaran aktif, inovatif, kreatif, dan menyenangkan (PAIKEM). PAIKEM adalah suatu proses pembelajaran yang bermakna yang dikembangkan dengan cara membantu peserta didik membangun keterkaitan antara informasi (pengetahuan) baru dengan pengalaman (pengetahuan lain) yang dimiliki dan dikuasai oleh peserta didik. Peserta didik belajar bagaimana konsep tersebut dapat di pergunakan diluar kelas dan diperkenalkan bekerja secara kooperatif (Agus Suprijono, 2010: 2)

Salah satu model pembelajaran yang dapat menjadi solusi untuk masalah yang berkaitan dengan partisipasi aktif siswa dalam pembelajaran untuk memahamai materi pelajaran adalah dengan menerapkan model Talking Stick. Model ini mampu mengaktifkan peserta didik serta merangsang peserta didik untuk berpikir ketika terjadi proses pembelajaran.

Model Talking Stick merupakan salah satu model yang yang menekankan pada keterlibatan peserta didik pada proses belajar mengajar, untuk berani mengemukakan pendapat. Model ini dapat memberikan motivasi kepada peserta didik supaya belajar aktif dalam memahami dan menemukan konsep, sehingga peserta didik mampu menghubungkan soal dengan teori yang ada.

Pada proses pembelajaran dengan menggunakan model talking stick guru harus mampu berperan sebagai motivator dan fasilitator agar proses pembelajaran dapat berlangsung dengan efektif, untuk itu guru harus memiliki wawasan pengetahuan yang luas dan mampu memanfaatkan teknologi modern, dan potensi lingkungan sekitar untuk dijadikan sebagai sumber belajar dan media pembelajaran.

Model pembelajaran talking stick melatih peserta didik untuk mampu menguji kesiapan peserta didik, melatih keterampilan peserta didik dalam membaca dan memahami materi pelajaran dengan cepat dan mengajak mereka untuk terus siap dalam situasi apapun, pembelajaran talking stick sangat cocok diterapkan bagi peserta didik, 
selain untuk melatih berbicara, pembelajaran ini akan menciptakan suasana yang menyenangkan dan membuat peserta didik aktif.

Model talking stick merupakan salah satu model yang menekankan pada keterlibatan peserta didik pada proses belajar mengajar, untuk berani mengemukakan pendapat (Betty Widya Asri, 2015: 70). Langkah-langkah model pembelajaran Talking Stick adalah : (1) guru menyiapkan tongkat dan kartu (2) guru menjelaskan tujuan pembelajaran (3) guru menyampaikan materi pokok yang akan dipelajari, kemudian memberikan kesempatan kepada peserta didik untuk membaca dan mempelajari materi lebih lanjut (4) setelah peserta didik selesai membaca materi/buku pelajaran dan mempelajarinya kemudian peserta didik menutup bukunya dan mempersiapkan diri menjawab pertanyaan dari guru (5) guru mengambil tongkat dan menyalakan musik kemudian peserta didik memulai menggilir tongkat dari peserta didik satu ke peserta didik yang lainnya (6) guru mematikan musik, dan peserta didik yang memegang tongkat dia yang harus mencabut nomor yang berisi pertanyaan kemudian peserta didik harus menjawab, demikian seterusnya sampai sebagian besar mendapat bagian untuk menjawab setiap pertanyaan dari guru (7) guru memberikan kesimpulan (8) Penutup (Suciani Kango, 2013: 4).

Kelebihan model pembelajaran Talking Stick adalah: (1) melatih konsentrasi dan kesiapan peserta didik (2) melatih daya ingat peserta didik (3) meningkatkan kreativitas peserta didik secara fisik,mental, intelektual, dan Emosional (4) melatih peserta didik berlatih berbicara didepan peserta didik yang lain (5) membantu peserta didik untuk giat belajar (6) dapat mengukur tingkat pemahaman peserta didik secara langsung dan secara Individu (7) terwujudnya pembelajaran yang menyenangkan karena ada unsur bermain. Kekurangan model pembelajaran Talking Stick yaitu jika guru tidak mengendalikan kondisi kelas, maka suasana kelas akan ribut (Suciani Kango, 2013: 4).

Suatu model pembelajaran akan maksimal dalam penerapannya jika dikombinasikan dengan media pembelajaran. Media pembelajaran mencakup semua peralatan fisik dan materi yang di gunakan dalam melaksanakan pembelajaran dan memfasilitasi tercapainya tujuan pembelajaran. Media ini merupakan bentuk dan saluran yang digunakan untuk menyampaikan informasi atau pesan.

Salah satua media yang dapat dikombinasikan dengan model pembelajaran talking stick adalah media Choose Number. Media ini merupakan salah satu permainan yang dapat digunakan untuk media pembelajaran agar peserta didik memiliki antusias dalam mengerjakan soal atau menjawab pertanyaan dalam pembelajaran itu sendiri. Media ini membantu konsentrasi peserta didik dalam menjawab pertanyaan yang diberikan oleh guru dan media ini juga melatih daya ingat peserta didik agar peserta didik tidak bosan dalam proses pembelajaran berlangsung (Heni Pratiwi, 2013: 2).

Kombinasi pemilihan model pembelajaran dengan media diharapkan mampu meningkatkan pemahaman peserta didik yang berakibat pada meningkatnya hasil belajar peserta didik, baik hasil belajar kognitif, afektif, maupun psikomotorik. Belajar tidak hanya penguasaan konsep teori mata pelajaran saja, tetapi juga penguasaan 
kebiasaan, persepsi, kesenangan, minat-bakat, penyesuaian sosial, macam-macam keterampilan, cita-cita, keinginan dan harapan ( Rusman, 2013: 123).

Media choose number juga merupakan permainan inovatif yang terinspirasi dari permainan lotre yang sering dilakukan anak-anak dimana anak dapat memilih salah satu angka atau huruf dan membuka isi di balik angka atau huruf tersebut, media pembelajaran ini sangat efektif untuk meningkatkan minat peserta didik selama proses pembelajaran. Media ini merupakan media yang banyak diminati anak-anak.

Hasil belajar adalah perubahan yang mengakibatkan manusia berubah dalam sikap dan tingkah laku. Aspek perubahan ini mengacu kepada taksonomi tujuan pengajaran yang dikembangkan oleh Bloom, Simpson, dan Harrow mencakup aspek kognitif, afektif, dan psikomotorik. Aspek kognitif berkaitan dengan pengetahuan dan pemikiran, aspek afektif berkaitan dengan sikap, sedangkan aspek psikomotorik berkaitan dengan keterampilan dan gerak tubuh. Evaluasi hasil belajar dapat dilakukan dengan menggunakan alat evaluasi yang berupa tes hasil belajar. Tes hasil belajar adalah tes yang dipergunakan untuk menilai hasil-hasil pelajaran yang telah diberikan guru kepada murid-muridnya. Oleh karena itu, seorang guru perlu mengetahui kemampuan peserta didiknya setelah terjadi proses pembelajaran dengan cara mengadakan tes. Hasil tes tersebut dapat berfungsi sebagai umpan balik bagi perbaikan proses belajar mengajar, dan dapat memberikan gambaran kenajuan belajar peserta didik bagi peserta didik

Faktor-faktor yang mempengaruhi hasil belajar sebagai berikut (1)Faktor biologis (jasmaniah) yaitu keadaan jasmani yang perlu diperhatikan, pertama kondisi fisik yang normal tau tidak memiliki cacat sejak dalam kandungan sampai sesudah lahir (2) Faktor psikologis yang mempengaruhi keberhasilan belajar ini meliputi segala hal yang berkaitan dengan kondisi mental seseorang (3) Faktor Kelelahan yaitu kelelahan dapat mempengaruhi belajar, agar peserta didik dapat belajar dengan baik haruslah menghindari jangan sampai terjadi kelelahan dalam belajarnya.

Tujuan dan fungsi hasil belajar yaitu (1) Memberikan umpan balik kepada guru dan peserta didik dengan tujuan memperbaiki cara belajar mengajar, mengadakan perbaikan dannpengayaan bagi peserta didik, serta menempatkan peserta didika pada situasi belajar mengajar yang lebih tepat sesuai dengan tingkat kemampuan yang dimilikinya (2) Memberikan informasi kepada peserta didik tentang tingkat keberhasilanya dalam belajar dengan tujuan untuk memperbaiki, mendalami atau memperluas pelajaranya (3) Menentukan nilai hasil belajar peserta didik yang antara lain dibutuhkan pemberian laporan kepada orang tua, penentuan kenaikan kelas, dan penentuan kelulusan peserta didik. Untuk mengetahui hal tersebut perlu diadakan pengukuran. Pengukuran adalah kegiatan yang dilakukan untuk mengumpulkan informasi. Informasi dalm upaya kemampuan menyerap materi pelajaran yang diberikan. "Salah satu caranya adalah dengan memberikan evaluasi yang rutin setiap akhir proses pembelajaran yang rutin setiap akhir proses pembelajaran yang berlangsung (Gunawan, 2015 : 30-31). 


\section{METODOLOGI PENELITIAN}

Jenis penelitian ini adalah Quasi Eksperimental Research yang merupakan desain yang mempunyai kelompok kontrol, tetapi tidak dapat berfungsi sepenuhnya untuk mengontrol variabel-variabel luar yang mempegaruhi pelaksanaan eksperimen. Penelitian ini bertempat di SMP Negeri 3 Sungguminasa Kabupaten Gowa. Populasi pada peserta didik kelas VIII SMP Negeri 3 Sungguminasa yang terdiri dari 10 kelas yang berjumlah 334. Teknik pengambilan sampel yang digunakan adalah simple random sampling dengan cara mengundi, pada tahap pertama yang dilakukan adalah menulis semua nama pada kelas yang akan menjadi populasi diatas potongan kertas kecil, kemudian kertas tersebut digulung, lalu dikumpulkan, dikocok dan diambil satu gulungan yang keluar dari hasil lot sebagai sampel kontrol. Kemudian peneliti menentukan kelas eksperimen cara yang akan dilakukan sama pada penentuan kelas kontrol hanya saja kelas kontrol yang akan terpilih tadi akan dikeluarkan atau tidak dipakai pada pengundiaan kedua. Setelah peneliti akan melakukan teknik tersebut maka peneliti mendapatkan sampel yang tediri dari dua kelas yaitu peserta didik pada kelas VIII H sebagai kelas kontrol dengan jumlah peserta didiknya 35 orang dan VIII A sebagai kelas eksperimen dengan jumlah peserta didiknya 35 orang.

Teknik pengumpulan data dalam penelitian ini menggunakan tes hasil belajar biologi dan observasi dengan menggunakan lembar Observasi/Pedoman observasi. Prosedur penelitian melalui beberapa tahapan yaitu (1) Melakukan observasi di SMP Negeri 3 Sungguminasa Kabupaten Gowa (2) Merumuskan suatu makna berdasarkan hasil observasi yang telah dilakukan (3) Peneliti menarik subjek penelitian dan menentukan sampel penelitian (4) Melakukan penentuan pokok bahasan yang akan diajarkan (5) Membuat RPP (Rencana Proses Pembelajaran) (6) Membuat kisi-kisi Postest (7) Membuat tes soal objektif untuk mengevaluasi hasil belajar (8) Menyusun kisi-kisi tes hasil belajar biologi (9) Buat tes soal objektif untuk mengevaluasi hasil belajar (10) Menyusun kisi-kisi dan soal tes hasil belajar biologi.

Teknik analisis data yang digunakan adalah teknik analisis data statistik dan deskriptif. Analisis statistik deskriptif dapat digunakan untuk mendeskripsikan hasil belajar biologi yang diperoleh peserta didik baik pada kelompok kontrol maupun pada kelompok eksperimen. Statistika inferensial menggunakan statistik dengan uji $t$ independen.

\section{HASIL PENELITIAN DAN PEMBAHASAN}

Deskripsi Hasil Belajar Peserta didik yang Diajar Menggunakan Model Talking Stick dengan Bantuan Media Choose Number ( Kelas Eksperimen )

Hasil belajar peserta didik yang diajar dengan menggunakan model talking stick dengan bantuan media choose number pada pembelajaran biologi dapat disajikan sebagai berikut: 
Tabel 1. Hasil Belajar Biologi Berdasarkan Prestest dan post test dengan menggunakan model Talking Stick dengan Media Choose Number

\begin{tabular}{llclllll}
\hline & $\mathrm{N}$ & Range & $\begin{array}{l}\text { Minimu } \\
\mathrm{m}\end{array}$ & $\begin{array}{l}\text { Maximu } \\
\mathrm{m}\end{array}$ & Mean & $\begin{array}{l}\text { Std. } \\
\text { Deviation }\end{array}$ & Variance \\
\hline Pretesteksperimen & 35 & 35.00 & 30.00 & 65.00 & 45.4286 & 10.31642 & 106.429 \\
Posttesteksperimen & 35 & 35.00 & 55.00 & 90.00 & 76.1429 & 8.49617 & 72.185 \\
Valid N (listwise) & 35 & & & & & & \\
\hline
\end{tabular}

Berdasarkan data yang telah diperoleh peneliti, maka akan dapat diketahui bahwa skor maksimum yang diperoleh pretest dengan menggunakan model pembelajaran talking stick dengan bantuan media choose number pada kelas VIII A adalah 65, sedangkan minimum adalah 30. Dan nilai rata-rata yang diperoleh adalah 45,42 dengan standar deviasi 10.31642 dan varians 106.429 yang menunjukkan tingkat keragaman data sedangkan pada skor maksimum yang diperoleh post-test dengan menerapkan model pembelajaran talking stick dengan bantuan media choose number pada proses pembelajaran kelas VIII A adalah 90 dan skor minimum 55. Jadi nilai ratarata yang diperoleh adalah 76,14 dengan standar deviasi 8.49617 atau varians 72.185. Menentukan frekuensi,nilai terendah pada kelas eksperimen (VIII A) pretest 30 dan postest 55 dan pengkategorian nilai tertinggi pada kelas eksperimen (VIII A) pretest 65 dan posttest 90 sedangkan nilai rata-rata pada kelas eksperimen pada pretest 45,01 dan posttest 75,58 sedangkan standar deviasi pada pretest 13,50 dan pada posttest 8,37 ”

\section{Deskriptif Hasil Belajar Peserta didik yang Diajar tanpa Model Talking Stick dengan Bantuan Media Choose Number Kelas Kontrol ( VIII H)}

Berdasarkan penelitian yang dilakukan di SMP Negeri 3 Sungguminasa pada siswa kelas VIII H, penulis mengumpulkan data dari instrumen tes melalui nilai hasil belajar pre-test dan post-test peserta didik tanpa diberi perlakuan model talking stick dengan bantuan media choose number. Untuk mengetahui hasi belajar biologi peserta didik tersebut dapat dilihat sebagai berikut:

Tabel 2. Tabel 1. Hasil Belajar Biologi Berdasarkan Prestest dan post test tanpa menggunakan model Talking Stick dengan Media Choose Number

\begin{tabular}{llllllll} 
& $\mathrm{N}$ & Range & $\begin{array}{l}\text { Minimu } \\
\mathrm{m}\end{array}$ & $\begin{array}{l}\text { Maximu } \\
\mathrm{m}\end{array}$ & Mean & $\begin{array}{l}\text { Std. } \\
\text { Deviation }\end{array}$ & Variance \\
\hline Pretekskontrol & 35 & 35.00 & 25.00 & 60.00 & 42.5714 & 10.17288 & 103.487 \\
$\begin{array}{l}\text { Posttekskontrol } \\
\text { talking stick }\end{array}$ & 35 & 35.00 & 50.00 & 85.00 & 67.5714 & 8.94192 & 79.958 \\
Valid N (listwise) & 35 & & & & & & \\
\hline
\end{tabular}

Data yang diperoleh peneliti, bahwa skor maksimum yang akan diperoleh pretest tanpa dengan menggunakan model talking stick dengan bantuan media choose 
number pada kelas kontrol adalah 60 dan skor maksimumnya 25 jadi rata-rata yang akan diperoleh yaitu 42,57 dengan menggunakan standar deviasi 10.17288 dan varians 103.487 sedangkan pada post-test pembelajaran pada kelas kontrol adalah 85 skor maksimum 50 nilai rata-rata yang akan diperoleh yaitu 65,57 dengan standar deviasi 8.94192 dan varians 79.958

Menentukan frekuensi, nilai terendah pada kelas kontrol VIII H pretest 25 dan pada postest 50 dan penkategorian nilai tertinggi pada pretest kelas kontrol 60 dan pada postest 85 , terlebih dahulu menghitung rentang nilai rata-rata dan menentukan nilai standar devisiasi pada pretest kelas kontrol 10,88 sedangkan posttest 9,52

Perbedaan Hasil Belajar Peserta Didik yang Menggunakan Model Talking Stick dengan Bantuan Media Choose Number dengan Hasil Belajar Peserta Didik yang Menggunakan Model Pembelajaran Konvensional

Pada bagian ini dilakukan analisis statistik inferensial untuk mengetahui apakah ada perbedaan yang signifikan terhadap penerapan model pembelajaran talking stick dengan bantuan media choose number dengan model pembelajaran konvensional terhadap hasil belajar peserta didik kelas VIII SMP Negeri 3 Sungguminasa. Sebelum melakukan inferensi, maka terlebih dahulu dilakukan uji asumsi sebagaimana yang ditampilkan pada tabel berikut:

Tabel 3. Uji Normalitas kelas eksperimen dan kelas kontrol

One-Sample Kolmogorov-Smirnov Test

\begin{tabular}{|c|c|c|c|}
\hline \multirow{2}{*}{\multicolumn{2}{|c|}{$\mathrm{N}$}} & posttesteksperimen & Posttestkontrol \\
\hline & & 35 & 35 \\
\hline \multirow[t]{2}{*}{ Normal Parameters $^{\mathrm{a}}$} & Mean & 76.1429 & 67.5714 \\
\hline & Std. Deviation & 8.49617 & 8.94192 \\
\hline \multirow[t]{3}{*}{ Most Extreme Differences } & Absolute & .132 & .136 \\
\hline & Positive & .125 & .136 \\
\hline & Negative & -.132 & -.121 \\
\hline \multicolumn{2}{|l|}{ Kolmogorov-Smirnov Z } & .782 & .804 \\
\hline \multicolumn{2}{|l|}{ Asymp. Sig. (2-tailed) } & .573 & .538 \\
\hline \multicolumn{4}{|c|}{ a. Test distribution is Normal. } \\
\hline
\end{tabular}

Pengujian normalitas yang bertujuan untuk menyatakan bahwa apakah data skor hasil belajar biologi materi sistem pencernaan untuk masing-masing kelas eksperimen (VIII A) dan kelas kontrol (VIII H) dari populasi berdistribusi normal. Berdasarkan hasil analisis One-Sample Kolmogorov-Smirnov Test data untuk kelompok Eksperimen (VIII A) yang diajar dengan model talking stick menggunakan media choose number, maka diperoleh nilai sig $=0.573$ (eksperimen) dan sig. $=0,538$ (kontorl) yang nilai sig. tersebut lebih besar dari $\alpha=0,05$, hal ini berarti data berdistribusi normal. 
Uji homogenitas bertujuan untuk melihat apakah data pada kedua kelompok memiliki varians yang sama (homogen) atau tidak, pengujian homogenitas dilakukan pada data hasil pretest dan postest kedua sampel, yang telah dirumuskan dalam penelitian ini. Dari hasil analisis pada tabel test of Homogenity of variances $\mathrm{F}=102$; df $1=1 ;$ df $2=68$; dan $\mathrm{p}$-value $=0,750>0,05$ atau $\mathrm{H}_{0}$ diterima. dengan demikian, data post-test hasil belajar homogen. Secara lengkap dapat dilihat pada tabel berikut:

Tabe 4. Uji homogeneitas varians

\section{Test of Homogeneity of Variances}

Nilai

\begin{tabular}{llll}
\hline Levene Statistic & df1 & df2 & Sig. \\
\hline .102 & 1 & 68 & .750 \\
\hline
\end{tabular}

Uji hipotesis dilakukan untuk mengetahui apakah dari hasil belajar peserta didik pada kelompok kontrol (VIII H) berbeda secara signifikan dengan hasil belajar peserta didik pada kelompok eksperimen (VIII A) yang diajar dengan model pembelajaran talking stick. Hipotesis penelitian akan diuji dengan kriteria pengujian yaitu jika $\mathrm{t}_{\text {hitun }}>\mathrm{t}_{\text {table }}$ dengan SPSS tarif signifikan $<\alpha$ (nilai sign $\left.<0.005\right)$ maka $\mathrm{H}_{0}$ ditolak dan $\mathrm{H}_{1}$ diterima dengan kriteria pengujian adalah jika Sign.hitung $>\alpha(0,05)$ maka $H_{1}$ diterima

dan $H_{0}$ ditolak, berarti terdapat perbedaan signifikan terhadap rata-rata hasil belajar

biologi yang diajar menggunakan model talking stick dengan bantuan media choose number pada kelas VIII di SMP Negeri 3 Sungguminasa. berarti ada perbedaan hasil belajar biologi materi sistem pencernaan peserta didik antara kelas eksperimen (VIII A) dengan kelas kontrol (VIII H).

Telah dikemukakan sebelumnya bahwa untuk pengujian hipotesis digunakan rumus uji t dengan tarif signifikansi $\alpha=0.05$. syarat yang harus dipenuhi untuk pengujian hipotesis adalah adalah data yang diperoleh berdidtribusi normal dan mempunyai varinsi yang homogen. Oleh karena itu sebelum peneliti melakukan pengujian hipotesis terlebih dahulu dilakukan uji normalitas dan uji homogenitas. Uji normalitas ini bertujuan untuk melihat apakah data tetang hasil belajar biologi tidak menyimpan dari distribusi normal dan tidak sedangkan uji homogenitas bertujuan untuk melihat apakah kedua kelompok tersebut berasal dari populasi yang homogenatau tidak" Secara statistika hasil analisis dapat dilihat pada tabel berikut: 
Independent Samples Test

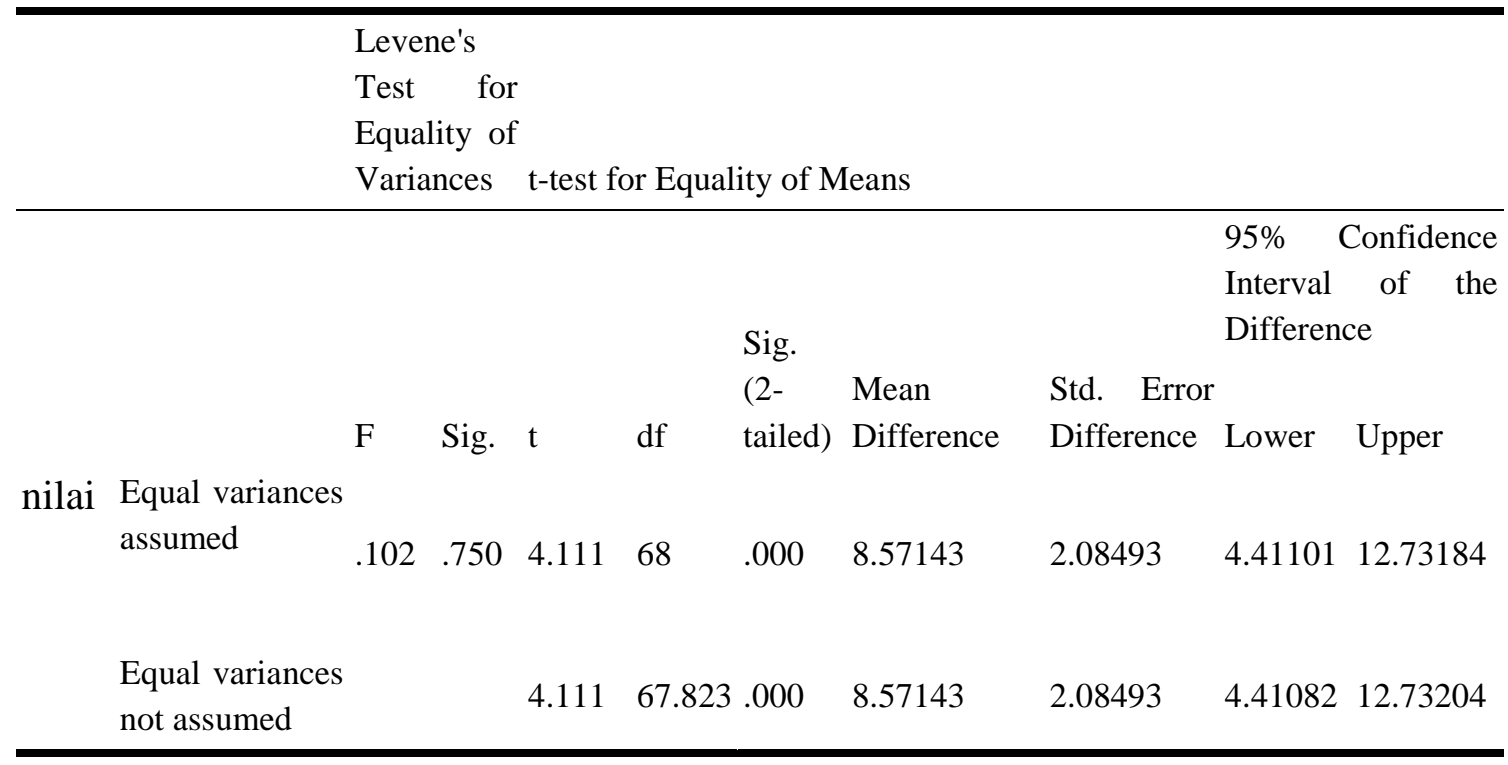

Berdasarkan dari hasil pengujian yang terlampir pada lampiran maka diperoleh nilai $\mathrm{t}_{\text {hitung }}=4,111>\mathrm{t}_{\text {tabel }}=2,655$ dengan taraf nyata $\alpha=0,05$ dan $\mathrm{df}=68$ sehingga $\mathrm{t}$ hitung berada pada daerah penolakan $\mathrm{H}_{0}$ yang berarti pada hipotesis $\mathrm{H}_{0}$ di tolak dan hipotesis $\mathrm{H}_{1}$ diterima. Sehingga dapat dikatakan bahwa dengan memanfaatkan model talking stick dengan media choose number dapat meningkatkan hasil belajar biologi pada materi sistem pencernaan peserta didik di kelas VIII SMP Negeri 3 Sungguminasa, hal tersebut menunjukkan bahwa ada perbedaan yang berarti antara kelas eksperimen (VIII A) dengan kelas kontrol (VIII H) dengan diterapkannya model talking stick dengan media choose number terhadap hasil belajar peserta didik.

Berdasarkan hasil penelitian yang telah dilaksanakan pada kelas eksperimen yang menggunakan model pembelajaran Talking stick dan kelas kontrol yang menggunakan model pembelajaran konvensional pada peserta didik kelas VIII di SMP Negeri 3 Sungguminasa berjumlah 70 peserta didik. Instrumen penelitian yang digunakan adalah 20 nomor pilihan ganda. Setelah memberikan tes terhadap peserta didik diperoleh data yang selanjutnya akan dianalisis.

Penerapan model talking stick dengan media choose number dalam proses belajar biologi materi sistem pencernaan pada kelas VIII A sangat positif bagi hasil belajar peserta didik dengan ditunjukan adanya peningkatan hasil belajar peserta didik. Suasana kelas aktif dan menyenangkan karena adanya unsur bermain, talking stick dengan bantuan choose number akan membuat peserta didik senang, talking stick dapat mengatasi kelemahan metode ceramah karena mampu meningkatkan keaktifan dalam proses belajar mengajar. Choose number adalah salah satu media grafis yang paling umum dipergunakan dalam proses pembelajaran, hal ini karena choose number memiliki kelebihan konkret, lebih realistis dapat memperjelas suatu masalah dalam bidang apa saja (Ida Bagus, 2014, 71). 
Hasil analisis data menunjukkan nilai rata-rata hasil belajar ipa(biologi) peserta didik kelas VIII H SMP Negeri 3 Sungguminasa diajar tanpa menggunakan model talking stick dengan media choose number adalah 67,41 dilihat dari post-test. Nilai rata-rata tersebut menunjukkan bahwa hasil belajar biologi pada materi sistem pencernaan peserta didik yang diajar tanpa menggunakan model talking stick menggunakan media choose number lebih rendah dibandingkan nilai rata-rata hasil belajar biologi materi sistem pencernaan peserta didik kelas eksperimen (VIII A) yang diajar dengan menggunakan model talking stick dengan media choose number 75,58. Nilai hasil belajar peserta didik setelah pemberian post-test pada kelas kontrol (VIII H) dalam kategori sedang yakni dengan persentase sebesar $40 \%$ dan peserta didik yang masuk ke dalam kategori tinggi yakni sebesar 11,43\% dari keseluruhan peserta didik. Hal ini terjadi karena pada kelompok kontrol yang diajarkan tanpa model talking stick dengan media choose number.

Hasil pengolahan data dengan menggunakan SPSS versi 16,0 pada analisis OneSample Kolmogorov-Smirnov Test data untuk kelompok eksperimen (VIII A) yang diajar dengan model talking stick dengan media choose number, maka diperoleh nilai $\mathrm{p}$ $=0,800$ (pretest) dan $\mathrm{p}=0,573$ (posttest) untuk $\alpha=0,05$, hal ini menunjukkan $\mathrm{p}>\alpha$. Ini berarti data skor hasil belajar biologi untuk kelompok eksperimen (VIII A) yang diajar dengan model talking stick dengan media berdistribusi normal. Sedangkan hasil analisis data untuk kelompok eksperimen yang diajar dengan tanpa model talking stick dengan media, diperoleh nilai $\mathrm{p}=0,475$ (pretest) dan $\mathrm{p}=0,538$ (posttest) untuk $\alpha=0,05$, hal ini menunjukkan $\mathrm{p}>\alpha$, ini berarti data skor hasil belajar klasifikasi makhluk hidup untuk kelompok kontrol yang diajar tanpa menggunakan model talking stick dengan media choose number berdistribusi normal, sehingga kedua kelompok tersebut berdistribusi normal.

Hasil pengolahan data dengan menggunakan SPSS versi 16,0 pada analisis OneSample Kolmogorov-Smirnov Test data untuk kelompok eksperimen (VIII A) yang diajar menggunakan model talking stick dengan bantuan media choose number, maka diperoleh nilai $\mathrm{p}=0,573$ untuk $=\alpha 0,05$, hal ini menunjukkan $\mathrm{p}>\alpha$. Ini berarti data skor hasil belajar biologi untuk kelompok eksperimen (VIII A) yang diajar menggunakan model talking stick dengan bantuan media choose number berdistribusi normal. Sedangkan hasil analisis data kelompok kontrol yang di ajar tanpa model talking stick dengan bantuan media choose number, diperoleh nilai $p=0,538$. Untuk $\alpha 0,05$, hal ini menunjukkan $\mathrm{p}>\alpha$ ini berarti data skor hasil belajar biologi untuk kelompok kontrol yang diajar tanpa menggunakan model talking stick dengan bantuan media choose number berdistribusi normal, sehingga data kedua kelompok tersebut berdistribusi normal. Berdasarkan uji levene statistic untuk kesamaan variance diperoleh nilai $\mathrm{p}=$ 0,750 hal ini menunjukan bahwa $\mathrm{p}>\alpha(0,750>0,05)$ yang berarti data skor hasil belajar kedua kelas adalah homogen.

Hasil pengolahan dengan SPSS 16 teknik pengujian yang digunakan adalah uji independet sample test dengan taraf signifikan $\alpha=0,05$. Berdasarkan hasil perhitungan Statistical Package For Social Science (SPSS) diperoleh nilai signifikan = 0,000 dan 
diperoleh $\mathrm{t}_{\text {hitung }}=4,111>\mathrm{t}_{\text {tabel }}=2,655$ sehingga dapat disimpulkan bahwa $\mathrm{H}_{0}$ ditolak dan $\mathrm{H}_{1}$ diterima karena nilai sig $<\alpha(0,000<0,05)$ dan $\mathrm{t}_{\text {hitung }}>\mathrm{t}_{\text {tabel }}(4,111>1,670)$. Sehingga dapat disimpulkan bahwa terdapat perbedaan yang signifikan terhadap hasil belajar biologi peserta didik yang menerapkan model talking stick menggunakan media choose number dengan peserta didik yang tanpa menggunakan model talking stick menggunakan media choose number di kelas VIII SMP Negeri 3 Sungguminasa.

Perbedaan hasil belajar yang nampak antara peserta didik yang diajar dengan model talking stick dengan media choose number dengan peserta didik yang diajar tanpa menggunakan model talking stick dengan media choose number dapat dilihat dari ratarata hasil posttest. Rata-rata pada kelompok eksperimen lebih tinggi dibandingkan dengan kelompok kontrol. Dari perbedaan ini dapat disimpulkan bahwa peserta didik yang diajarkan dengan model talking stick dengan bantuan media choose number memberikan pengaruh yang signifikan terhadap hasil belajar biologi pada materi sistem pencernaan peserta didik kelas VIII SMP Negeri 3 Sungguminasa.

\section{KESIMPULAN}

Berdasarkan penelitian dan pengolahan data hasil penelitian, maka dapat disimpulkan yaitu (1) Hasil belajar peserta didik pada bidang studi biologi yang menerapkan model talking stick dengan bantuan media choose number di kelas VIII A SMP Negeri 3 Sungguminasa Kab. Gowa adalah 75,58 pada nilai rata-rata post-tesnya dan nilai ratarata pretest adalah 45,01 (2) Hasil belajar peserta didik pada bidang studi biologi tanpa menerapkan model talking stick dengan bantuan media choose number di kelas VIII H SMP Negeri 3 Sungguminasa Kab. Gowa adalah 67,41 pada nilai rata-rata post-tesnya dan nilai rata-rata pretest adalah 43 (3) Terdapat perbedaan hasil belajar peserta didik yang menerapkan model talking stick dengan bantuan media choose number dengan peserta didik tanpa diajar dengan model talking stick dengan bantuan media choose number, dimana peserta didik nilai rata-rata tinggi dibandingkan nilai rata-rata peserta didik yang tanpa diajar yang menerapkan model talking stick dengan media choose number memiliki menggunakan model talking stick dengan media choose number.

\section{DAFTAR PUSTAKA}

Asri, Widya, Betty. (2015) .'Peningkatan kualitas pembelajaran PKN Menggunakan Model Talking Stick dengan Menggunakan Audio-Visual".

Budimansyah, dasim. (2002). Model pembelajaran dan penilaian. Bandung : Genesindo.

Gunawan. (2015). Efektivitas Penerapan Metode Word Square (WS) Dalam Meningkatkan Hasil Belajar Matematika Pada Peserta didik Kelas XI SMA Negeri 11 Makassar" Skripsi” Makassar : Fakultas Tarbiyah dan keguruan UIN Alauddin,. 
Hamalik, Oemar. (2001). Proses Belajar Mengajar. Cet. Pertama ; Jakarta : PT Bumi Aksara.

Kango Suciani,dkk. ( 2013) “Pengaruh Model Pembelajaran Kooperatif Tipe Talking Stick Terhadap Hasil Belajar Peserta didik Kelas IV SDN 3 Bulawa Pada Materi Hubungan Daya Alam, Lingkungan,Teknologi dan Masyaraka.

Pratiwi, Heni. (2013). "Peningkatan Minat Belajar Melalui Strategi Instant Assessment dengan Media Choose Number Pada Mata Pelajaran IPS Peserta didik Kelas IV SD Muhammadiyah 2 Kauman Surakarta”.

Rusman. (2013). Belajar dan pembelajaran berbasis komputer. Cet. 11; Bandung: Alfabeta.

Suprijono, Agus. (2014). Cooperative Learning, Teori dan Aplikasi Paikem. Cet. IV; Yogyakarta: Pustaka Pelajar.

Sugiono, : (2014). metodePenelitian Pendidikan. Cet. XX; Bandung: Alfabeta, 2014.

Syamsuduha, St. Penilaian berbasis kelas konsep dan Aplikasi Cet 1 ; yogyakarta : CV. Arti Bumi Intaran.

Widoyono dan Sofara, (2013). Metodologi penelitian sosial untuk penulisan skripsi dan tesis. Cet 1 ; jakarta : In Media. 